\title{
O DISCURSO DE REGIONALIZAÇ̃̃O NO LIVRO DIDÁTICO DO ENSINO MÉDIO LEARN AND SHARE IN ENGLISH
}

\author{
EL DISCURSO DE REGIONALIZACIÓN EN EL LIBRO DIDACTICO DE LA \\ ENSEÑANZA SECUNDARIA LEARN AND SHARE IN ENGLISH
}

\section{THE DISCOURSE OF REGIONALIZATION IN THE TEXTBOOK OF HIGH SCHOOL LEARN AND SHARE IN ENGLISH}

\author{
José Rosamilton de LIMA ${ }^{1}$ \\ Ciro Leandro Costa da FONSÊCA ${ }^{2}$
}

RESUMO: Neste artigo analisa-se o discurso de regionalização linguística e cultural no livro didático Learn and share in English. Este trabalho baseia-se teoricamente nos estudos de Albuquerque Júnior (2011), Foucault (2008a; 2008b; 2008c), nos PCNs (1998), PCNs+ (2006), DCNEB (2013), entre outros. O corpus trata-se de gêneros de discurso que trazem enunciados em que estão materializados discursos referentes à diversidade linguística e cultural da língua inglesa no cenário mundial, observando que tendências regionais prevalecem. Como categorias de análise utiliza-se o discurso, o enunciado, o sujeito e a Formação Discursiva. Foi constatado que a discursividade foi construída a favor de um ensino de inglês com foco na norma culta padrão, principalmente, britânica e norte-americana. Portanto, na sociedade contemporânea em que a Inglaterra e os Estados Unidos dominam a economia mundial, aprender inglês é um privilégio social que permite situar o aluno numa aldeia global.

PALAVRAS-CHAVE: Discurso. Regionalização. Livro didático.

RESUMEN: En este artículo se analiza el discurso de regionalización lingüistica y cultural en el libro didáctico Learn and share in English. Este trabajo se basa teóricamente en los estudios de Albuquerque Júnior (2011), Foucault (2008a, 2008b, 2008c), en los PCN (1998), PCNs + (2006), DCNEB (2013) entre otros. El corpus se trata de géneros de discurso que traen enunciados en que se materializan discursos referentes a la diversidad lingüistica y cultural de la lengua inglesa en el escenario mundial, observando cuales tendencias regionales prevalecen. Como categorías de análisis se utiliza el discurso, el enunciado, el sujeto y la Formación Discursiva. Se constató que la discursividad fue construida a favor de una enseñanza de inglés con foco en la norma culta, principalmente, británica y norteamericana. Por lo tanto, en la sociedad contemporánea en que Inglaterra y los Estados Unidos dominan la economía mundial, aprender inglés es un privilegio social que permite situar al alumno en una aldea global.

PALABRAS CLAVE: Discurso. Regionalización. Libro didáctico.

${ }^{1}$ Secretaria de Estado da Educação e da Cultura, Jose da Penha - RN - Brasil. Professor Permanente Nível V da Rede Estadual de Ensino. Mestrado em Letras (UERN). ORCID: https://orcid.org/0000-0003-3819-7067. E-mail: rosamiltonlima@hotmail.com

${ }^{2}$ Educandário Raízes do Saber, Luís Gomes - RN - Brasil. Coordenador Pedagógico. Doutorado em Letras (UERN). ORCID: https://orcid.org/0000-0003-4444-4642.E-mail: ciro.leandrorn@gmail.com 
ABSTRACT: In this work is analyzed the discourse of linguistic and cultural regionalization in the textbook Learn and share in English. This work is theoretically based in the studies by Albuquerque Junior (2011), Foucault (2008a; 2008b; 2008c), PCNs (1998), PCNs+ (2006), DCNEB (2013) among others. The corpus is composed of discourse genres that bring statements in which are materialized discourses referring to linguistic and cultural diversity of the English in the world, observing that regional trends prevail. As analysis categories is used the discourse, the statement, the subject and the discursive formation. It was verified that the discursiveness was built in favor of the standard cultured norm, mainly, British and North American. Therefore, in the contemporary society where England and The United States dominate the world economy, to learn English is a social privilege that allows to situate the student in a global village.

KEYWORDS: Discourse. Regionalization. Textbook.

\section{Introdução}

Para auxiliar o professor na busca de melhorias no ensino, o Ministério da Educação e Cultura - MEC, tem buscado criar e apoiar programas que contribuem para esse propósito, dentre eles pode ser exemplificado os Programas do Livro. Vale salientar que em 1985 surgiu o Programa Nacional do Livro Didático - PNLD, a partir do Decreto no 91.542 de 19/08/85, que teve como finalidade distribuir livros escolares aos estudantes matriculados nas escolas públicas de $1^{\circ}$ grau. De acordo com o referido decreto, professores devem participar das análises e indicar os títulos a serem adotados, assim como participar de avaliações permanentes dos livros adotados de modo a aprimorar o processo de seleção (BRASIL, 1985).

A participação do professor nesse processo é fundamental para que o material não se distancie das práticas pedagógicas da escola e seja de fato uma ferramenta utilizada pelo docente da educação básica como um auxílio para aprendizagem do aluno. No entanto, este profissional da educação deve apresentar um perfil que demonstre um engajamento e comprometimento com a educação no componente curricular que leciona. Ele deve apresentar uma boa formação na sua área de conhecimento, no intuito de que a teoria não esteja dissociada da prática, visto que o inglês do Livro Didático - LD - é diferente do falado na rotina do estudante, que costuma ter o contato com o idioma em músicas, filmes, seriados, charges, cartuns e jogos.

Para tanto, como se trata de língua estrangeira moderna, o aluno da educação básica que está cursando o ensino médio possui de 15 a 17 anos, exceto se estiver em defasagem de idade e série. Logo, o adolescente em processo de formação de identidade inserido no meio social necessita de uma compreensão global de língua e cultura ao redor do mundo, como também, 
conhecer e refletir sobre a sua própria região, com a finalidade de agir criticamente sobre a realidade na localidade de residência.

Este trabalho objetiva analisar o discurso de regionalização linguística e cultural presente no LD de língua inglesa para o ensino médio, para o triênio 2018 a 2020, adotado pela Escola Estadual Vicente de Fontes. As análises ocorrerão a luz da teoria da Análise do Discurso na vertente francesa. Assim, será analisado como corpus o discurso constituído de enunciados presentes em gêneros de discurso que são propostos no LD. Trata-se de textos que fazem parte de uma Formação Discursiva - FD - em que se atribui como verdade a escolha de determinadas modalidades de língua e cenários culturais como adequados ao contexto brasileiro e ao ensinoaprendizagem de inglês.

Para tanto, será verificado qual ideologia é proposta pelo LD no tocante à língua e cultura, e como o referido material destinado para alunos brasileiros vem construindo identidades linguísticas e culturais, também será observado que regularidades discursivas são apresentadas através de enunciados e imagens na fabricação dos dizeres e visibilidades que representam a vontade de verdade a respeito da regionalização linguística e cultural no LD. Ademais, será identificado que posição sujeito esse material didático assume na formação da identidade do estudante aprendiz da língua inglesa, considerando ambos os aspectos mencionados sobre a regionalização.

Além disso, deseja-se analisar a coleção do ensino médio Learn and share in English por ser um material recente que está disponível para os aprendizes brasileiros como ferramenta principal para formação de sua identidade no tocante à língua inglesa. Nesse contexto, o LD surge como suporte relevante para aprendizagem do aluno, visto que propõe para estudo discursos que circulam no contexto social nas variadas esferas discursivas. A enunciação discursiva é materializada em diversificados textos que compõem os gêneros de discurso, apresentando conteúdos linguísticos e culturais fundamentais para o indivíduo na sociedade contemporânea.

Este trabalho é relevante porque reflete sobre a necessidade de compreender a diversidade regional como modo de formar uma identidade plural linguística e cultural, conduzindo o aluno aprendiz de língua inglesa a reconhecer e respeitar as variadas formas de linguagens e cultura. Nesse sentido, ele deve situar-se como um cidadão global que valorize seu contexto social, ao mesmo tempo em que promova uma autorreflexão para busca de qualidade de vida na sociedade na qual está inserido. Logo, como professor de educação básica, que utiliza o livro didático como ferramenta na prática pedagógica, é fundamental um olhar crítico no referido material com foco na regionalização linguística e cultural para os processos 
de subjetivação e a formação de identidade dos estudantes do interior nordestino, que na maioria das vezes, se autodenominam incapazes de aprender a língua inglesa.

A partir deste estudo, almeja-se que se forme uma percepção crítica do professor na condução do LD, tratando de despertar no aluno a compreensão das diferentes manifestações linguísticas e culturais em países falantes do inglês, observando porque algumas variedades são mais usadas na sociedade contemporânea. Nesse sentido, o professor, enquanto produtor de discursos que influenciam na formação estudantil, deve contribuir na criação de uma identidade em que se compreenda as transformações sociais diante a complexidade da sociedade contemporânea que o aluno vivencia tempos de globalização, e precisa se situar linguística e culturalmente em regionalizações para obter êxito pessoal e profissional.

$\mathrm{O}$ artigo, além das considerações iniciais e finais, é constituído de duas partes. $\mathrm{Na}$ primeira, é feito um breve relato a respeito do LD de inglês para o ensino médio. Ademais, há comentários relacionados à abordagem sociointeracional preconizada pelos documentos oficiais brasileiros que orientam o ensino desse componente curricular, como também é apresentada a definição de regionalização. $\mathrm{Na}$ segunda parte, analisa-se o discurso de regionalização linguística e cultural no $\mathrm{LD}$, observando como esse material didático situa o aluno discursivamente no tocante ao ensino-aprendizagem de inglês, tendo como categorias de análise o discurso, o enunciado, o sujeito, a memória discursiva e a Formação Discursiva - FD. Assim, apresenta-se os conceitos básicos da $\mathrm{AD}$ que sustentam a análise, de forma que eles sejam explicados por meio de recortes do próprio corpus, contribuindo para que teoria e análise teçam um diálogo.

\section{O Livro Didático e a abordagem sociointeracional}

O LD é uma ferramenta fundamental para o processo de ensino-aprendizagem. Esse material deve ser atual, atrativo, dinâmico, interativo e que enfatize uma abordagem metodológica-didática que atenda às necessidades dos alunos na sociedade contemporânea. Desse modo, ao longo dos anos o PNLD vem se aprimorando e em 2012 incluiu o LD de Língua Estrangeira, inglês e espanhol, para a escolha no ensino médio, sendo uma novidade para os profissionais desses componentes curriculares. Nesse contexto, o livro tem vigência de três anos. Vale ressaltar que houve outra escolha em 2015, e em 2018 foi a terceira vez que foram escolhidos livros para essa modalidade de ensino. Para o triênio 2018 a 2020, o LD de Língua Estrangeira - LE - não é mais consumível e, portanto, deve ser reutilizado, isto é, os alunos devem devolver no final do ano letivo para que outros possam utilizá-los no ano seguinte. 
Nas duas edições passadas, os exemplares de inglês eram repostos todos os anos e entregues aos alunos para que pudessem completar os exercícios e fazerem anotações no próprio livro. Segundo Sarmento 2016, p. 27, “é muito importante que eles possam se utilizar dos espaços para anotações de forma a não perderem tempo tendo de copiar as atividades no caderno". Logo, essa determinação do MEC é um retrocesso, já que existe uma dificuldade de se trabalhar com o material didático de LE devido a diversos fatores, tais como: o desinteresse dos alunos por causa do número reduzido de aulas, turmas superlotadas e heterogêneas, baixo vocabulário do alunado, falta de ambiente acústico adequado para se trabalhar a compreensão oral, rotina atribulada do trabalho docente com jornada dupla de trabalho, dentre outros.

Conforme o Guia do Livro Didático - GLD - 2012, foram inscritas 20 coleções de Inglês para avaliação do MEC e foram aprovadas 7, sendo assim, 35\%. Em 2015, segundo o GLD 2015 foram inscritas 14 coleções, sendo 4 aprovadas, ou seja, 29\%. Em 2018, segundo o GLD 2018 foram inscritas 15 coleções desse componente curricular e foram aprovadas 05 , isto é, $33 \%$. Pode ser inferido, a partir desses dados, que há uma análise rigorosa do MEC na avaliação do $\mathrm{LD}$, com base em critérios pedagógicos determinados por esse órgão com a finalidade de que é para chegar ao aluno um material de qualidade em um país com dimensões continentais, em que se deve contemplar valores linguísticos e culturais em uma abrangência global, ao mesmo tempo em que se propague a valorização da cultura local do estudante pela grande diversidade do Brasil. Dessa forma, vamos analisar uma das coleções aprovadas pelo MEC e escolhida pela Escola Estadual Vicente de Fontes, em José da Penha, no Rio Grande do Norte. A coleção possui como autores Amadeu Marques e Ana Carolina Cardoso, publicado pela editora Ática.

O LD deve ser elaborado dentro de uma perspectiva sociointeracional e deve estar fundamentado nos documentos norteadores, a saber: Parâmetros Curriculares Nacionais para o Ensino Médio (PCNEM), as Orientações Curriculares para o Ensino Médio (OCEM), as Orientações Educacionais Complementares aos Parâmetros Curriculares Nacionais do Ensino Médio (PCN+) e a Matriz de Referência de Linguagens, Códigos e suas Tecnologias do Exame Nacional do Ensino Médio (ENEM).

Dessa forma, a coleção baseada nesses documentos pode propiciar ao estudante a concepção de cidadania, fomentando uma reflexão a respeito da posição que ele ocupa na sociedade, para que seja capaz de enfrentar os desafios cotidianos e sociais de vida, conforme necessário a usos diversos da linguagem em determinados ambientes, fazendo uma autocrítica ao universo cultural e linguístico ao qual está inserido, observando fatores como a linguagem, costumes, crenças, tradições e modo de pensar. Ademais, é imprescindível o cuidado que se 
deve ter na produção do material didático, pois o Brasil possui dimensões continentais, com cinco regiões diferentes.

Vale salientar que a regionalização é um processo de diferenciação e/ou recorte do espaço em parcelas coesas ou articuladas. Por exemplo, o Brasil é dividido em cinco regiões distintas por seu bioma, por aspectos culturais, econômicos, e assim por diante. Por isso, possui uma grande variedade de dialetos e sotaques. Logo, regionalizar é agrupar por semelhança, adotando critérios específicos, nesse agrupamento, os quais podem ser físicos, econômicos ou históricos. Em se tratando do planeta, pode ser dito que o critério físico está relacionado à divisão dos continentes, política, bioma, localização das terras, etc., o econômico à divisão dos países de acordo com o Índice de Desenvolvimento Humano - IDH, os países do Norte (desenvolvidos) e do Sul (subdesenvolvido), e por fim, o critério histórico que diz respeito à divisão em primeiro mundo, segundo mundo e terceiro mundo, a colonização, dentre outros.

A regionalização diz respeito à ação que os sujeitos produzem no espaço e na interação que eles estabelecem na sociedade. Portanto, para determinar a regionalização deve ser considerado o conjunto de regularidades de práticas discursivas com imagens e textos que caracterizam diversos aspectos que estão unidos por alguns critérios que resultam de criações históricas, imaginárias e simbólicas formadas ao longo dos anos. De acordo com Albuquerque Júnior (2011, p. 35), “definir a região é pensá-la como um grupo de enunciados e imagens que se repetem com certa regularidade, em diferentes discursos, em diferentes épocas, com diferentes estilos e não a pensar uma homogeneidade, uma identidade presente na natureza".

Contextualizando para o ensino brasileiro, a visão sociointeracional defende que a aprendizagem de uma língua estrangeira ocorra por meio da interação com o meio social, com o professor e com outros colegas de classe. Pois, "aprender é uma forma de estar no mundo social com alguém em um contexto histórico, cultural e institucional” (BRASIL, 1998, p. 57). Assim, é a linguagem que possibilita um contato com o mundo. Ela é uma forma de interação social, sendo que a língua está materializada nos gêneros de discurso.

O LD deve ser escolhido para atender as necessidades do aluno e deve estar em consonância com o Projeto Político Pedagógico da escola. Por isso, ele necessariamente tem que ser apropriado e instigante para que por meio da interação com os colegas, com o professor e com o meio social seja construído o aprendizado. Na visão sociointeracional, a linguagem é concebida como uma forma de interação, é o resultado de uma construção coletiva e de processos de interação que não podem ser desvinculados do processo de produção na sociedade. A linguagem possui função social e comunicativa que possibilita ao homem o contato com o 
mundo, isto é, no contexto escolar, o estudante constrói o conhecimento na interação com o outro.

$\mathrm{Na}$ perspectiva dialógica a língua representa o uso comunicativo, sendo vista em um contexto sócio-histórico que ultrapassa a fronteira da sistematização e abstração, não se limitando somente aos aspectos linguísticos. Nessa abordagem considera-se a presença do outro, pois a língua não é um ato individual, visto que o discurso é dirigido a interlocutores concretos que também estabelecem uma relação dialógica com o mundo. É através da interação na sociedade, com o uso de gêneros de discurso, que o estudante compreenderá a funcionalidade da língua e será capaz de produzir enunciados e utilizá-los em diferentes situações sociais para que lhe proporcionem uma comunicação eficiente. É a partir do trabalho com gêneros que é possível um aprendizado cultural e linguístico que contribui para a formação do estudante na sociedade, de forma a compreendê-la criticamente e exercer cidadania.

$\mathrm{Na}$ sociedade contemporânea é necessário que a escola disponibilize material que promova reflexões críticas sobre diversificados temas envolvendo a cidadania, contribuindo assim para a formação de um pensamento sem preconceito e discriminação no tocante à grande diversidade linguística e cultural, seja no Brasil ou no mundo. Para tanto, é fundamental que o LD apresente diversificados gêneros de discurso que abordem temas como estilos diferentes de vida, linguagens, costumes, crenças, dentre outros, estimulando o aluno por meio de atividades para uma cultura de combate às diversas formas de preconceito e discriminação, porque "o ambiente escolar é um lugar que concentra muitos jovens em processo de formação de identidade. Portanto, a escola é um local propício para que se possa diminuir a discriminação e as diversas formas de preconceito" (LIMA, 2012, p. 37).

Logo, conforme preconiza o edital do PNLD 2018, há a preocupação que os LDs contemplem os mais diversos grupos sociais e sejam tratados de maneira positiva e com respeito. No tocante à regionalização, está associada a dialetos padrão e linguajares locais, por isso, não se pode discriminar a linguagem do estudante, como também, a situação socioeconômica, política, seus costumes, questões de espaço geográfico e sociocultural. A regionalização sociocultural corresponde à avaliação das condições sociais e culturais, inserindo neste contexto o índice de desenvolvimento humano para explicitar como vivem as pessoas em determinado lugar. De acordo com os $\mathrm{PCNs}+(2006$, p. 98):

A construção da identidade cultural parte da consciência da necessidade de se construir a identidade linguística, constituída pelo estudo da conservação e das rupturas, da posição dos interlocutores em dado momento histórico, das negociações de sentido, intenções e expectativas envolvidas. 
Pode ser dito que o indivíduo deve dominar múltiplas linguagens, conhecer e respeitar diversificadas culturas para ser capaz de inserir-se com mais facilidade no mercado de trabalho, assim como, conseguir ascensão social. Dessa forma, o aprendizado de língua inglesa possibilita um acesso direto à produção cultural dos países falantes desse idioma e permite a comunicação com o mundo por se tratar de uma língua universal.

\section{Análise sobre o discurso de regionalização no livro Learn and share in English}

Analisa-se o discurso de regionalização presente no LD do ensino médio Learn and share in English. Para tanto, utiliza-se como categorias o sujeito, os enunciados, a FD, a memória discursiva e o discurso presente no referido manual didático. Como corpus serão utilizados os livros das $1^{\mathrm{a}}, 2^{\mathrm{a}}$ e $3^{\mathrm{a}}$ séries do ensino médio (Livro do Aluno - LA), focando o olhar para fatores de regionalização relacionados à língua e cultura. Pretende-se verificar que dizeres o LD propõe na fabricação da verdade por meio das relações de poder, qual modelo linguístico e cultural é proposto como adequado para o ensino-aprendizagem de língua inglesa.

Em um pôster, no LA, $1^{\circ}$ ano, p. 37, há a palavra "biscuits". Veja a figura 1:

Figura 1 - Pôster

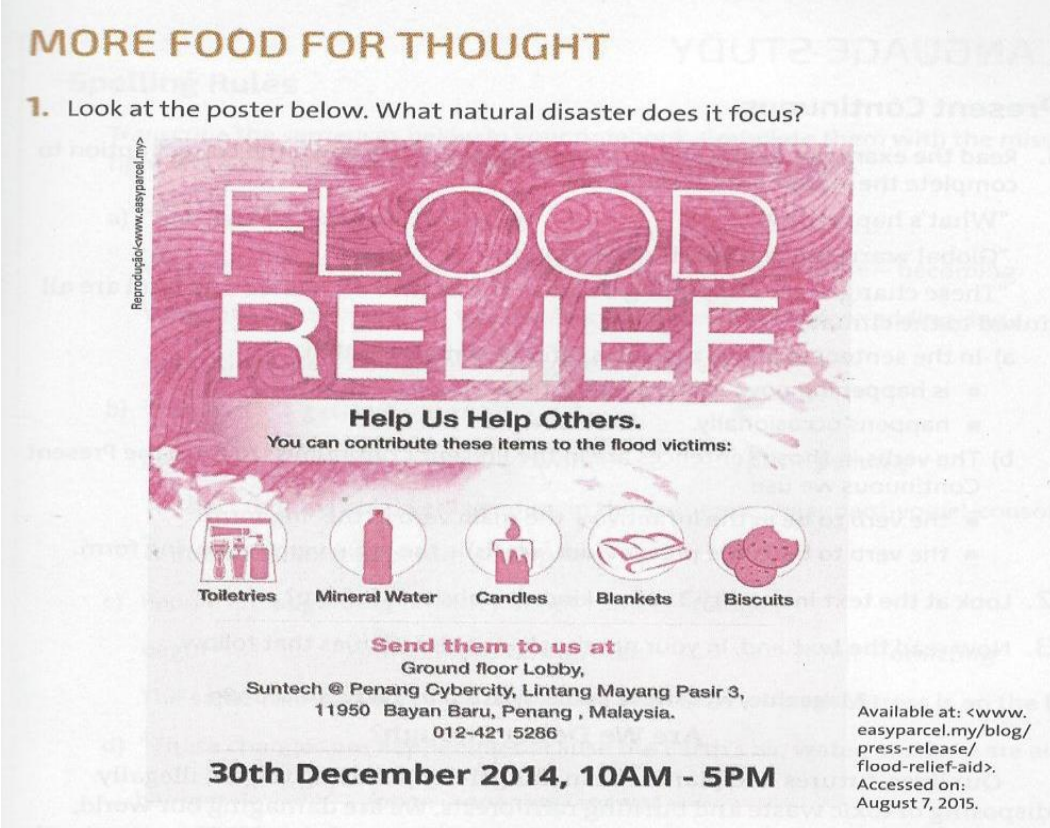

Fonte: Marques (2016)

Nesse contexto, a palavra biscuits é britânica e o LA não traz nenhuma nota explicativa, como por exemplo, mostrando a opção de cookies utilizada no inglês norte-americano. Além disso, no que se refere ao aspecto cultural a partir do enunciado presente no texto "Help us help 
others" é possível perceber a solidariedade do povo britânico perante os desastres naturais que afetam a população e deixam as pessoas fragilizadas emocional e financeiramente.

Então, pode se dizer que em país como a Inglaterra há uma corrente de solidariedade para ajudar as pessoas a se recuperarem desses desastres. O professor pode instigar o aluno a retomar a memória discursiva e questionar sobre a ocorrência de enchentes no Brasil, ou na localidade onde ele vive. Por exemplo, é comum ocorrerem enchentes em algumas regiões brasileiras. Entretanto, no interior da região nordeste há uma situação contrária à enchente, pois é comum a estiagem por um longo período. O professor pode estimular o aluno a fazer uma reflexão sobre esse tema, verificando se existe solidariedade das pessoas no enfrentamento desse problema natural, se existem campanhas de outros nordestinos ou da população brasileira com doações para ajudar ao povo sertanejo no enfrentamento da seca.

Vale salientar que para entrar na ordem do discurso é necessário ser qualificado, ou seja, deve-se satisfazer a determinadas exigências para adentrar-se nas regiões do discurso. Para que ele ocorra, é necessária uma contextualização daquilo que pode e que deve ser dito. Logo, são os discursos que produzem as verdades de um certo momento histórico. Não há uma maneira de produzir discurso de forma absolutamente livre, porque ele é sempre controlado, à medida em que são postos certos enunciados ao invés de outros, ocorrem silenciamentos, retomadas à memória discursiva, para que a produção de sentidos possua aceitação no social, cultural e histórico, ou seja, há um silenciamento quanto ao inglês norte-americano. Nesse sentido, o LD pode ser visto como um documento de identidade porque pode trazer discursos que negociam identidades ao ser utilizado por professores e alunos, pois ele pode contribuir para a permanência de identidades hegemônicas ou abrir espaço para que apareçam novas identidades.

Quando o manual didático dá preferência em considerar um padrão de linguagem, como por exemplo a britânica, sem apontar outras possibilidades, está implícita uma relação de força que influenciará na identidade do sujeito, que ao adentrar na aprendizagem de uma língua considerada adequada, mergulha-se também na ideologia do país que propaga essa linguagem. Assim, o sujeito se inscreve no social e é ideologicamente marcado, historicamente produzido e transformado. O aluno é direcionado a entender a importância do inglês britânico para o usuário deste idioma, como também, é levado a conhecer características culturais de uma nação em uma região socioeconômica de primeiro mundo, e confrontar com o espaço socioeconômico em que reside, para que possa buscar soluções de melhoria para sua vida.

No LA do $1^{\mathrm{o}}$ ano, na página 15 , é apresentada uma tirinha por uma organização australiana. Veja a figura 2: 
Figura 2 - Tirinha

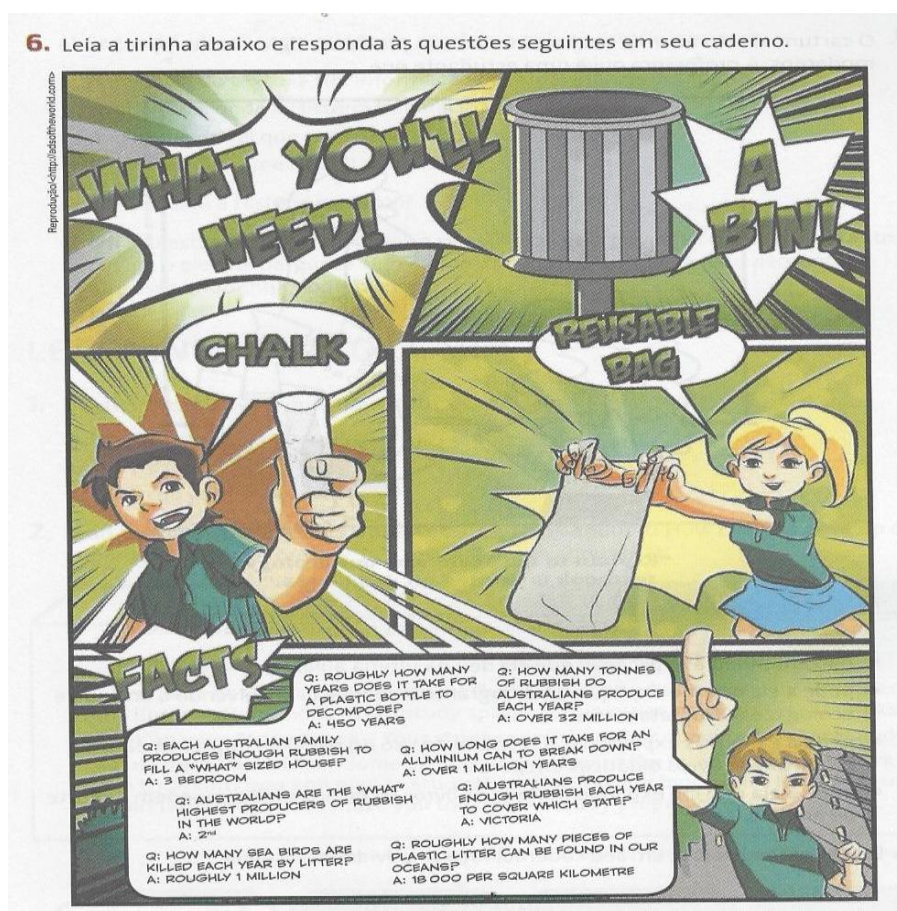

Fonte: Marques (2016)

Como pode ser visto, é trabalhado o inglês utilizado em uma outra região do planeta fora da Inglaterra, muito embora o vocábulo "rubbish" seja do inglês britânico, que se diferencia do inglês norte-americano "garbage" ou "trash". Percebe-se que mais uma vez é silenciado o inglês norte-americano, porque embora esteja sendo apresentado o australiano, ele está próximo ao britânico. Desse modo, o aluno pode ser conduzido a perceber que esse idioma está presente de forma oficial em mais um continente, em outras palavras, em mais uma região do planeta. Ademais, analisando o aspecto cultural verifica-se nos enunciados "What you 'll need", "chalk", "reusable bag", "a bin" e "facts", há uma preocupação do sujeito enunciador, uma organização ambientalista, em conscientizar os australianos, principalmente os jovens, para os problemas ambientais.

$\mathrm{Na}$ tirinha são apresentadas 8 questões com suas respectivas respostas que tratam do problema do lixo que atinge as famílias australianas, mas que, também, é um problema mundial. Percebe-se que há um discurso que traz fatos impactantes sobre o tema em destaque, no intuito de chamar atenção do público-alvo para criar uma consciência de cuidados no destino final do lixo para preservação do meio ambiente. Logo, o professor disponibilizando este texto, e adotando a sugestão de atividade de interpretação proposta pelo LA, deve explorar essa temática em sala de aula. Nesse caso, não há no LA questões propostas pelo referido manual que estimule a exploração de contrapontos e semelhanças entre a preservação ambiental na região da 
Austrália e no Brasil, o que não impede que o professor use seu conhecimento cultural e experiência para fazer essa conexão.

Ademais, na página 21 deste mesmo livro há um texto que contempla o inglês australiano e uma nota explicativa com o vocábulo Flavour. Veja a figura 3:

Figura 3 - Nota explicativa com o vocábulo Flavour

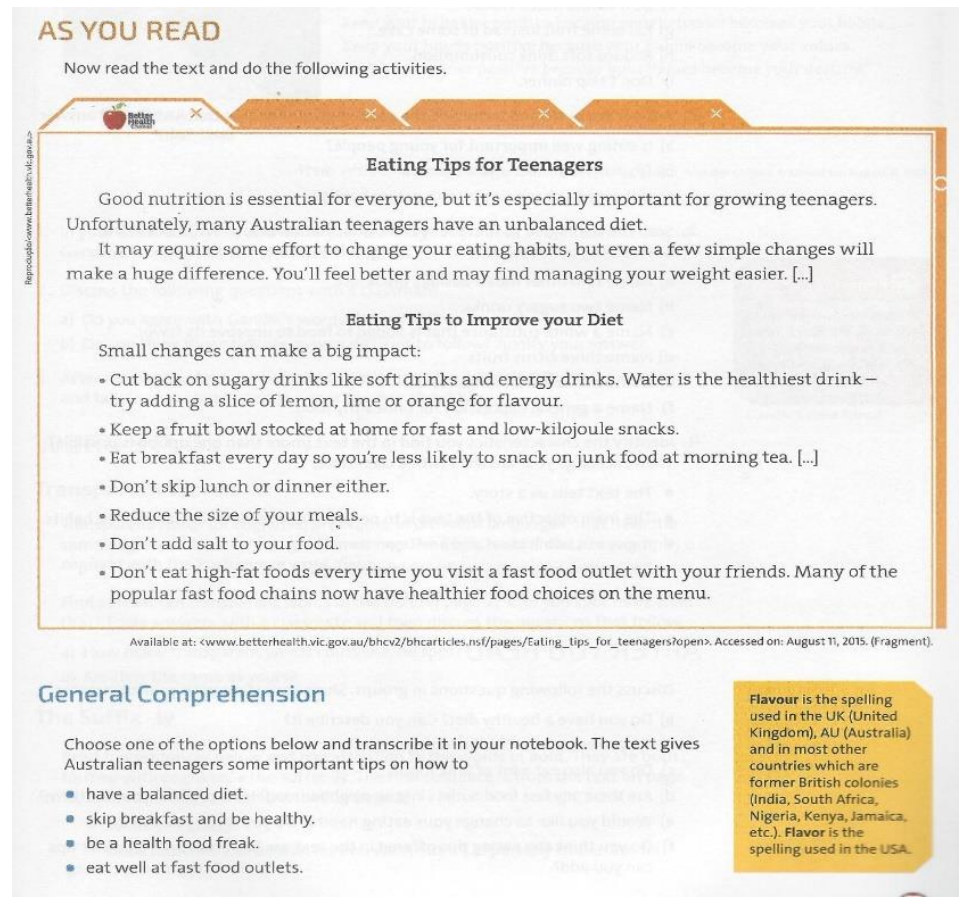

Fonte: Marques (2016)

Ao propor o trabalho a partir desse texto, podem ser explorados aspectos linguísticos e culturais dos jovens australianos, visto que possibilita ao aluno brasileiro fazer uma reflexão sobre hábitos alimentares entre essas duas regiões do planeta distantes geograficamente, considerando semelhanças e divergências no intuito de que, ao compreender sua cultura, ele seja capaz de pensar seu comportamento alimentar para propiciar melhorias na sua vida.

O discurso presente no texto direciona o adolescente brasileiro ao entendimento de costumes e hábitos alimentares de pessoas na mesma faixa etária, que embora estejam distantes geograficamente podem estar ligados culturalmente através de modos comportamentais diante de uma necessidade básica do ser humano. Assim, o discurso tornará possível operar o elo necessário entre o nível propriamente linguístico e o extralinguístico. Logo, o discurso é algo que está exterior à língua, mas que precisa dela para ter uma existência material. Por isso, é relevante que se compreenda a língua como recurso que possibilita a comunicação humana. Nesses termos, pode se pensar que: 
O discurso nada mais é do que a reverberação de uma verdade nascendo diante de seus próprios olhos; e, quando tudo pode, enfim, tomar a forma do discurso, quando tudo pode ser dito e o discurso pode ser dito a propósito de tudo, isso se dá porque todas as coisas, tendo manifestado e intercambiado seu sentido, podem voltar à interioridade silenciosa da consciência de si (FOUCAULT, 2008a, p. 49).

Como pode ser visto, o discurso exerce poder na vida das pessoas, e no tocante à regionalização há uma seleção de recortes por meio de diversificados enunciados, textos que compõem uma dada FD, representada pelo LD que prioriza a língua e cultura de uma determinada região, o inglês britânico e de países que foram colônias da Inglaterra, pois, a regionalização pode ser entendida como a divisão de um espaço ou território em unidades de áreas que explicitam características que as individualizam. Logo, regionalização pode ser estabelecida segundo diferentes critérios que podem ser físicos, socioeconômicos, linguísticos, culturais, etc. Além disso, a nota explicativa reforça a postura do sujeito autor do LD em valorizar a ideologia britânica como berço linguístico do inglês que expandiu a língua para diversas colônias ao redor do mundo.

$\mathrm{Na}$ unidade 4, na questão que pergunta a profissão de Marta Vieira da Silva, a resposta é "She's a soccer player", não havendo nenhuma menção a outras variedades (LA, $1^{\circ}$ ano, p. 69). No livro do $2^{\circ}$ ano na página 19 , o texto sobre telefones celulares emprega, na pergunta 1 , as palavras "cell phones", que são do inglês norte-americano, sem mencionar formas usadas em outras variedades da língua inglesa. Já no livro do $3^{\circ}$ ano, na página 95, na pergunta, “How are women in Cameroon breaking some of the country's stereotypes?", é possível ver duas formas de vocabulário presentes, geralmente associadas às variedades americanas e britânicas "They are playing football/soccer". Ademais, no livro do $2^{\circ}$ ano, na página 25 , na questão 3 da Seção Language study que trata de verbos modais na forma negativa, há uma nota ligada à resposta da questão 3, informando que "A forma mayn't, ainda que usada em British English, é hoje muito pouco comum".

De acordo com Francescon, Senefonte e Baronas (2013, p. 2011), “dentro de uma mesma comunidade, podem ocorrer variações devido a fatores políticos, de escolaridade, de gênero, religiosos, econômicos, entre outros. Todavia, a variação também pode ocorrer entre diferentes comunidades, devido a fatores geográficos, principalmente". Logo, não existe uma variedade de língua melhor do que outra, porém, países como os Estados Unidos e a Inglaterra possuem um poderio político, econômico e bélico e, consequentemente, de certa forma, impõem sua língua como um modelo padrão a ser seguido, visto que muitos países que desejam 
manter relacionamentos comerciais, científicos, políticos, etc. com os norte-americanos e britânicos devem manter contato utilizando a língua inglesa.

A partir disso, pode-se inferir que o mencionado material didático prioriza o inglês britânico e norte-americano, embora ocorram casos em que apareçam textos relacionados à Austrália. Isso ocorre devido às relações de poder presentes no meio social, ou seja, ambas as modalidades de língua inglesa são, na contemporaneidade, as que possuem maior importância devido à expansão econômica, poder bélico e hegemonia dessas duas nações mundiais. De acordo com Foucault (2008b, p. 8):

O que faz com que o poder se mantenha e que seja aceito é simplesmente que ele não pesa só como uma força que diz não, mas que de fato ele permeia, produz coisas, induz ao prazer, forma saber, produz discurso. Deve considerálo como uma rede produtiva que atravessa todo o corpo social muito mais do que uma instância negativa que tem por função reprimir.

Na página 29 do livro do $2^{\circ}$ ano, há uma nota explicativa sobre o uso coloquial do verbo "going to". Isso pode ser considerado um fator positivo, tendo em vista que há uma preocupação em mostrar o uso de uma situação real de comunicação, mesmo que não se utilize a norma culta, mas se houver comunicação é uma ação válida. Dando sequência, no LA do $2^{\circ}$ ano, na página 30, há um texto enfatizando o uso de gírias usadas na comunicação através da internet. Veja a figura 4: 
Figura 4 - Gírias usadas na comunicação através da internet

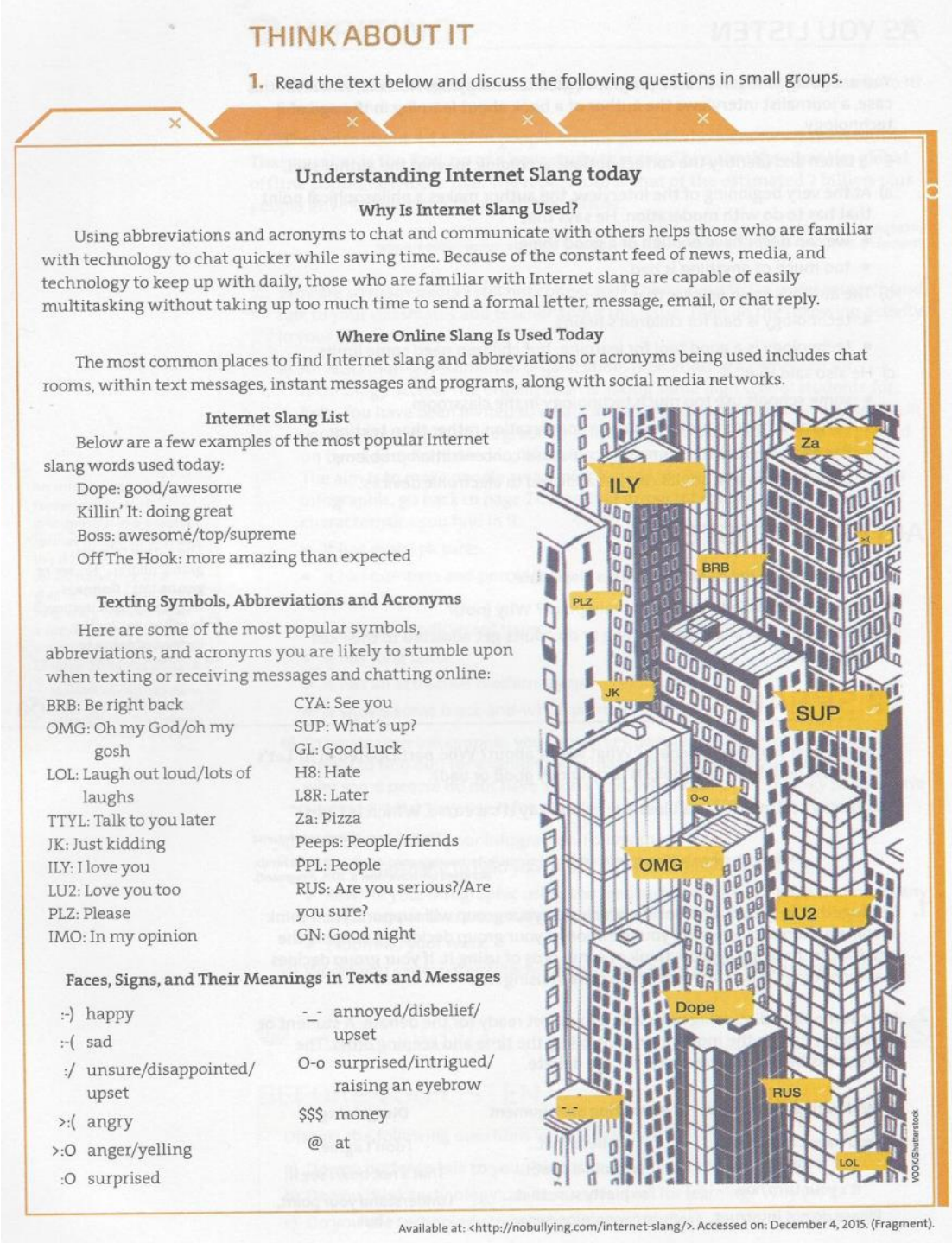

Fonte: Marques (2016)

Um texto assim costuma despertar o interesse do aluno, pois proporciona o debate de uma temática que faz parte da rotina do estudante, porque é uma forma muito frequente de comunicação, rápida, dinâmica que permite a interação entre milhares de pessoas no mundo, sem estar limitado ao espaço geográfico regional. Como consequência disso, há muitas comunidades virtuais que são constituídas por membros de diferentes partes do mundo, mas que se identificam pelos seus pensamentos, costumes, ideologias, formas de se vestirem, de se comportarem e de falarem. Conforme os $\mathrm{PCN}+(2006$, p. 100), “é indispensável, também, que as aulas de língua estrangeira moderna possibilitem o estudo de grupos culturais (migrantes, rappers, por exemplo) a partir de seus usos linguísticos". Esse tipo de inglês pode ser 
considerado universal, porque surge a partir do meio tecnológico em comunidades virtuais espalhadas pelo mundo, até mesmo, onde o inglês não é idioma oficial.

Ainda na sequência, na página 31 do livro do $2^{\circ}$ ano, há uma nota explicativa sobre internetês:

\begin{abstract}
Netspeak (or cyber-slang), the internet slang known as internetês in Portuguese, is the kind of linguistic variety people use on the internet for the sake of brevity and objectivity when sharing information and communicating with one another. That kind of language may be suitable for informal situations on the internet, but it is not considered appropriate use of language in formal situations (MARQUES, 2016, p. 31).
\end{abstract}

Esse enunciado reforça a importância de mostrar a diversidade linguística e explicita o uso real da língua em situações do dia a dia das pessoas ao utilizarem o inglês quando estão na internet, comunicando-se com milhares de pessoas pelas diferentes regiões do planeta. Assim, o discurso presente no LD evidencia a necessidade de um entendimento que o indivíduo deve fazer uso de diferentes linguagens para uma comunicação global, sem que esteja limitado a uma região geográfica.

Além disso, no LA do $3^{\circ}$ ano, na página 13 , há uma situação semelhante, pois há um cartum que ilustra a necessidade do professor utilizar a internetês para se comunicar com seus alunos, o que causou espanto neles, já que no ambiente de sala de aula não se trata de uma situação usual, tendo em vista que na maioria das vezes o docente usa a língua formal por meio da oralidade. Porém, o efeito humorístico é que o professor foi obrigado a utilizar o internetês para adentrar no universo do aluno que, embora pressionado pelas regras e normatização escolar, insistem em se distanciar da escola fugindo para comunidades virtuais.

A página 80 do LA, do $2^{\circ}$ ano, enfatiza a diversidade cultural e linguística, explicitando a pluralidade de línguas espalhadas pelo planeta, e menciona, também, essa diversidade no mesmo país. Logo, a proposta é apresentada por meio de um cartum. Veja a figura 5: 
Figura 5 - Diversidade cultural e linguística

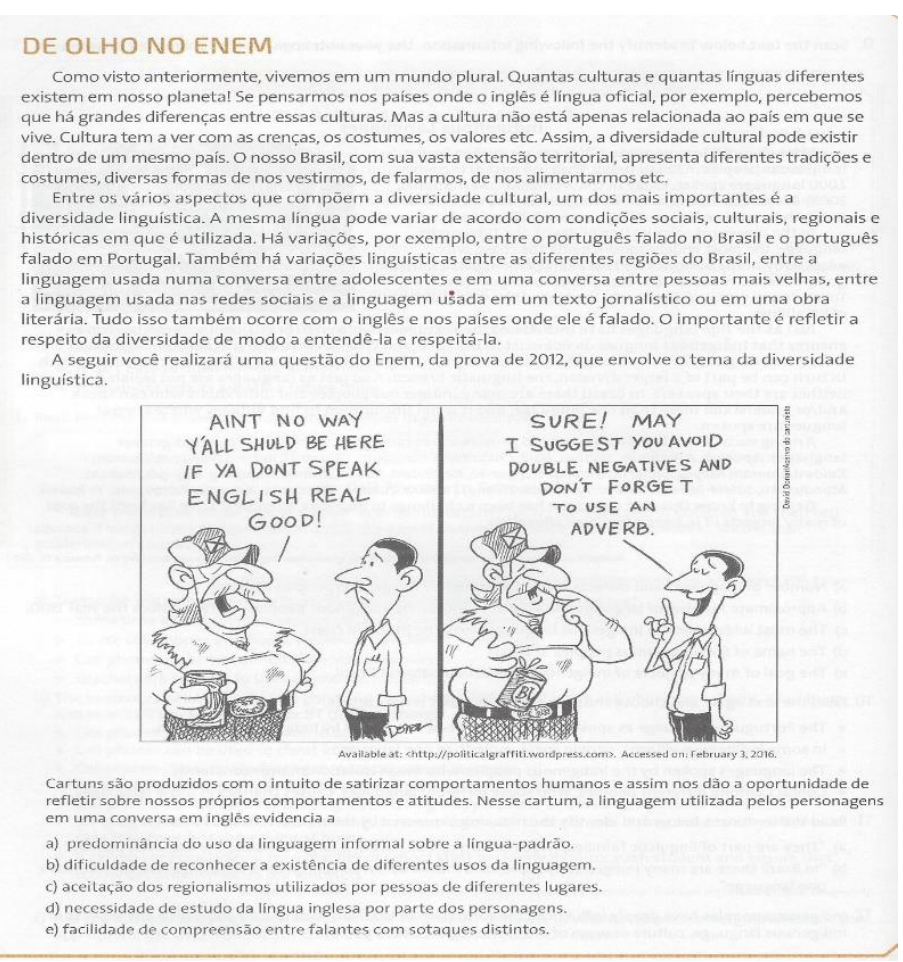

Fonte: Marques (2016)

É interessante mencionar que a língua expressa a forma de comunicação de um povo refletindo sua cultura e deve ser respeitada, pois não existe idioma melhor que outro. Logo, os enunciados: "aint no way y'all shuld be here if ya dont speak english real good!" e "Sure! May I suggest you avoid double negatives and don't forget to use an adverb", representam um discurso de discriminação em que um dos personagens possui dificuldades em reconhecer outras formas de linguagem que não seja a norma culta padrão.

Nesse caso, o professor a partir desse texto, possui material para explicar a necessidade do aluno de compreender e respeitar diferentes variedades linguísticas e culturais. Porém, para obter êxito profissional e satisfação pessoal o falante de inglês necessitará conhecer principalmente a variedade britânica e norte-americana da norma culta, por serem mais privilegiadas socialmente no contexto globalizado atual, devido ao poder econômico dessas duas regiões no cenário mundial. No entanto, o aluno deverá possuir criticidade e maturidade linguística para respeitar a pluralidade linguística e cultural existente nos diferentes espaços sociais. Porém, vale ressaltar que o LD faz menção ao inglês universal utilizado pela internet como forma de comunicação na contemporaneidade. Segundo Albuquerque Júnior (2011, p. $35)$ : 
Em nenhum momento, as fronteiras e territórios regionais podem se situar num plano a-histórico, porque são criações eminentemente históricas e esta dimensão histórica é multiforme, dependendo de que perspectiva de espaço se coloca em foco, se visualizado como espaço econômico, político, jurídico ou cultural, ou seja, o espaço regional é produto de uma rede de relações entre agentes que se reproduzem e agem com dimensões espaciais diferentes.

Foi verificado que o LD analisado prioriza como modalidade de língua o inglês britânico e norte-americano, assim como faz referência a outras variações como a australiana e a canadense. Vale salientar também que o sujeito, autor do LD, mostra a relevância da variação linguística, e destaca o internetês como possibilidade de comunicação que é bastante utilizada, principalmente, nas redes sociais. Desse modo, toda identidade do discurso são construções feitas através do próprio discurso, por isso permeável de movências de sentidos. Quando um discurso é proferido, ele já nasce filiado a uma rede tecida por outros discursos com semelhantes escolhas e exclusões, pois existem os discursos iniciais que influenciam, mas não são influenciados.

Há os discursos que "se dizem" no decorrer dos dias e das trocas, e que passam com o ato mesmo que os pronunciou; e os discursos que estão na origem de certo número de atos novos de fala que os retomam, os transformam ou falam deles, ou seja, os discursos que, indefinidamente, para além de sua formulação, são ditos, permanecem ditos e estão ainda por dizer (FOUCAULT, 2008a, p. 22).

Nesse sentido, o discurso é uma prática social que se exterioriza do enunciado. Ele é constituído de enunciados que pertencem a um saber de uma determinada época, sendo um lugar onde se entrecruzam filiações a memórias que retomadas sempre deslocam sentidos. As palavras adquirem sentidos a partir das FDs que elas provêm. O sentido é interpretado a partir da posição do sujeito. O discurso só existe a partir da interpretação da relação do leitor com o texto, isto é, ele é efeito de sentido entre os interlocutores que se materializa no texto. Não existe neutralidade no discurso, pois o sujeito sempre fala a partir de uma posição assumida numa determinada conjuntura social. Por exemplo, para proposta de um LD, o sujeito autor deve atender a diversas determinações do MEC. Entretanto, seu discurso não é neutro, porque é apresentado um discurso ideológico no tocante a língua e cultura que ele acredita serem mais apropriados para o estudante brasileiro aprendiz de inglês no ensino médio na sociedade contemporânea.

O sujeito discursivo integra uma instância social, coletiva, que é constituída em um espaço de enunciação. Ele é heterogêneo porque muda de lugar e posição. Logo, esse lugar social exteriormente e historicamente produzido e modificado atua na constituição desse 
sujeito. Assim, os autores do LD, como também o MEC, que aprova e disponibiliza esse material para as escolas de todo o país, assumem a posição de sujeito que propõe uma forma de saber considerada verdadeira no contexto contemporâneo, tendo em vista os 3 anos de duração do curso de ensino médio, e direcionada para o aluno brasileiro aprendiz de inglês.

Na página 52 do livro do $3^{\circ}$ ano há uma nota explicativa sobre o uso da palavra major no Canadá e nos Estados Unidos. Entretanto, ao longo da coleção existem várias notas explicativas que trazem essas diferenças entre Estados Unidos e Inglaterra, como por exemplo no livro do $2^{\circ}$ ano nas páginas 109: ageing $(U K)=\operatorname{aging}(U S A)$ e 132: litre $(A U, U K)=$ liter (USA), assim como, no livro do $3^{\circ}$ ano nas páginas 123: organised (UK) = organized (USA); Centre $(U K)=$ Center $(U S A), 131$ : programme $(U K)=$ program (USA) e 132: enrol, enrolment $(U K)=$ enroll, enrollment (USA). Vale ressaltar que todas essas palavras são explicadas porque aparecem em gêneros de discurso que são propostas de trabalhos do LD, ou seja, em situações reais de comunicação. O PCN+ (2006, p. 101) delimita que "o estudo da língua estrangeira permite a reflexão sobre o idioma e a cultura como bens de cidadania, além de contribuir para a eliminação de estereótipos e preconceitos".

Nesse ínterim, foi constatado que a coleção reúne um conjunto de textos representativos das comunidades falantes da língua inglesa, contemplando algumas regiões do planeta, que utilizam diferentes variedades da língua inglesa para abordar assuntos a respeito dessas diversificadas comunidades. Logo, "um saber se define por possibilidades de utilização e de apropriação oferecidas pelo discurso" (FOUCAULT, 2008c, p. 204).

Acrescenta-se ainda que o discurso é um todo organizado, mas não fechado, há espaço para que novos e outros sentidos se formem. $\mathrm{O}$ discurso se renova à medida que se entrelaça nos outros. É por isso que o sentido do discurso não é a única prioridade, já que a unidade é construída pela interação verbal, que é histórica e mantém relação com uma ideologia. Há a instância puramente ideológica onde se congregam grupos sociais de dominantes e dominados.

Desse modo, não podemos dizer simplesmente o que queremos, visto que os nossos dizeres só adquirem sentido se obedecerem a ordem do discurso, que por sua vez é estabelecida pelas relações de poder, um poder disciplinar que está impregnado na conjuntura social. Por exemplo, para que o sujeito autor do LD tenha seu material utilizado na sala de aula nas escolas brasileiras é necessário atender a vários critérios definidos pelo MEC. Então, “o discurso está na ordem das leis; que há muito tempo cuida de sua aparição; que lhe foi preparado um lugar que o honra mas o desarma; e que, se lhe ocorre ter algum poder, é de nós, só de nós, que ele advém" (FOUCAULT, 2008a, p. 7). 
As nossas práticas sociais são formadas a partir das informações que recebemos, e, portanto, a identidade está sempre em processo contínuo. No contexto do LD a discursividade construída em torno da identidade do indivíduo é para que ele seja formado como cidadão reconhecedor de diversos comportamentos, hábitos e costumes da cultura inglesa e das variantes da língua, mas que para ser bem sucedido pessoal e profissionalmente na sociedade contemporânea, ele deve priorizar a cultura e conhecimentos linguísticos da norma culta britânica e norte-americana. Assim, conforme as Diretrizes Curriculares Nacionais da Educação Básica (2013, p. 170-171),

as instituições escolares devem avaliar as várias possibilidades de organização do Ensino Médio, garantindo a simultaneidade das dimensões trabalho, ciência, tecnologia e cultura e contemplando as necessidades, anseios e aspirações dos sujeitos e as perspectivas da realidade da escola e do seu meio.

\section{Considerações finais}

Na sociedade contemporânea em que Inglaterra e Estados Unidos dominam a economia mundial, aprender inglês é um privilégio social. Assim, pelos enunciados presentes ao longo da coleção, a discursividade foi construída a favor do ensino de inglês com foco na norma culta padrão, principalmente, britânica e norte-americana. Porém, embora o LD dê maior prioridade ao discurso britânico e norte-americano, o mesmo já propõe uma significativa contribuição para o aprendiz de língua inglesa porque permitirá compreender aspectos relacionados à conjuntura social, econômica, política, cultural e linguística desses dois países, para por meio disso observar pontos que se assemelham ou se contrapõem ao seu próprio país. Ademais, se reconhece a importância da variação linguística e a internetês como forma de comunicação nas redes sociais no mundo globalizado na sociedade contemporânea.

Dessa forma, o LD possui influência na formação educacional do estudante, por ser na maioria das vezes, a principal ferramenta pedagógica utilizada pelo professor em sala de aula. Assim, tendo como corte cronológico os 3 anos do ensino médio, a formação da identidade do indivíduo está imbuída com a formação discursiva determinada pelo LD, que preconiza como um saber padrão, principalmente, a norma culta britânica e norte-americana no tocante ao conhecimento linguístico daquilo que deve e pode ser dito nesta sociedade contemporânea, como também, viabiliza o acesso à cultura dos mencionados países. Então, o LD pode ser considerado como uma FD, porque representa o saber que deve ser adquirido pelo aluno brasileiro no período de 3 anos, durante o curso do ensino médio. Pois, as escolhas dos recortes linguístico e cultural presentes no $\mathrm{LD}$, nas propostas de atividades, possibilitam a criação ou 
não de determinadas identidades em um determinado espaço social e/ou geográfico em um determinado período. Isto é, o LD possibilita uma identidade do aluno voltada para um mundo globalizado, compreendendo e respeitando a pluralidade linguística e cultural, situando-se como entendedor do meio social em que vive, e a partir dele, busque através da língua e cultura conquistar qualidade de vida.

Espera-se com este trabalho provocar uma reflexão a respeito dessa temática, por se tratar de um assunto relevante que permite uma reflexão crítica a respeito de um manual didático em sua ótica sobre o discurso de regionalização no cenário mundial contemporâneo. Logo, a vivência do indivíduo constrói o conhecimento social, cultural e linguístico do ambiente em que se interage, e o LD como ferramenta pedagógica contribui para a formação intelectual do estudante e, consequentemente, para sua identidade como sujeito da sociedade na qual está inserido. Portanto, em um mundo globalizado com a pluralidade cultural, a identidade linguística não pode estar presa a um ideal de pureza que aponta apenas para duas nações que possuem o domínio da economia mundial. Aprender inglês proporciona ao sujeito na sociedade contemporânea a autoconfiança necessária para enfrentar o mercado de trabalho global e destacar-se nele como profissional capacitado para uma carreira de êxito.

\section{REFERÊNCIAS}

ALBUQUERQUE JÚNIOR, D. M. A invenção do nordeste e outras artes. 5. ed. São Paulo: Cortez, 2011.

BRASIL. Ministério da Educação. Parâmetros curriculares nacionais: terceiro e quarto ciclos do ensino fundamental. Língua estrangeira. Brasília: Secretaria de Educação Fundamental, 1998.

BRASIL. Ministério da Educação. PCN+ Ensino Médio. Orientações Educacionais Complementares aos Parâmetros Curriculares Nacionais. Brasília: Secretaria de Educação Básica, 2006. Disponível em: http://portal.mec.gov.br/seb/arquivos/pdf/linguagens02.pdf. Acesso em: 23 nov. 2018.

BRASIL. Guia de livros didáticos: PNLD 2012: língua estrangeira moderna: Brasília: Ministério da Educação, Secretaria de Educação Básica, 2011.

BRASIL. Ministério da Educação. Diretrizes Curriculares Nacionais da Educação Básica. Brasília: Secretaria de Educação Básica, 2013.

BRASIL. Guia de livros didáticos: PNLD 2015: língua estrangeira moderna: ensino médio. Brasília: Ministério da Educação, Secretaria de Educação Básica, 2014. 
BRASIL. Ministério da Educação. PNLD 2018: inglês - guia de livros didáticos - ensino médio. Ministério da Educação - Secretaria de Educação Básica - SEB - Fundo Nacional de Desenvolvimento da Educação. Brasília, DF: Ministério da Educação, Secretaria de Educação Básica, 2017.

FRANCESCON, P. K; SENEFONTE, F. H. R; BARONAS, J. E. A. Variação linguística no ensino de língua inglesa. Revista Entrelinhas, São Leopoldo, v. 7, n. 2, jul. \dez. 2013.

FOCAULT, M. A ordem do discurso. Aula inaugural no Collège de France, pronunciada em 2 de dezembro de 1970. Trad. Laura Fraga de Almeida Sampaio. 16. ed. São Paulo, Edições Loyola, 2008a.

FOCAULT, M. Microfísica do poder. Trad. Roberto Machado. Rio de Janeiro: Edições Graal, 2008b.

FOCAULT, M. A arqueologia do saber. Trad. Luiz Felipe Baeta Neves. 7. ed. Rio de Janeiro. Forense Universitária, 2008c.

LIMA, J. R de. O desafio da escola em trabalhar com a diversidade. Revista Memento, Três Corações, v. 3, n. 1, jan.|jul. 2012.

MARQUES, A. Learn and share in English: língua estrangeira moderna: inglês. 1. ed. São Paulo: Ática, 2016.

SARMENTO, S. ReVEL na escola: programa nacional do livro didático de língua estrangeira. ReVEL [online], v. 14, n. 26, 2016.

\section{Como referenciar este artigo}

LIMA, J. R.de; FONSÊCA, C. L. C. da. O discurso de regionalização do livro didático do ensino médio Learn and share in English. Rev. EntreLínguas, Araraquara, v. 6, n. 2, p. 370390, jul/dez. 2020. e-ISSN: 2447-3529. DOI: https://doi.org/10.29051/el.v6i2.13559

Submetido em: 12/04/2020

Revisões requeridas: $02 / 06 / 2020$

Aprovado em: 05/07/2020

Publicado em: 30/09/2020 